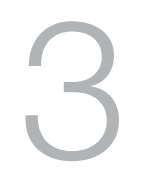

\title{
Walvin, Fitzpatrick and Rickard: Three Autobiographies of Childhood and Coming of Age
}

\author{
Doug Munro and Geoffrey Gray
}

Once a comparatively rare beast, historians' autobiographies are becoming prevalent to the point of being commonplace. Since the 1980s, such works have crystallised into a genre and have become a historiographic growth area. Limiting the head count to monograph-length works, a dozen historians' memoirs were published in the 1970s, rising to three dozen in the 1980s, five dozen in the 1990s, and the contributions continue apace. ${ }^{1}$ Once on the fringes of the historical enterprise, historians' memoirs are now edging closer to centre stage. Increasing frequency has lent respectability. There remain significant pockets of resistance, the usual canards being that autobiography is inescapably egotistical, self-indulgent and narcissistic. Nonetheless, the genre is rapidly gaining acceptance and being treated seriously - and not simply historians' autobiographies but autobiography by academics generally. Almost without exception, historians' autobiographies contain a chapter or chapters on childhood and coming of age. In parallel with the increasing prevalence of historians' autobiographies, a subgenre devoted to the childhoods through to the

1 The figures, which are conservative, are taken from Jeremy D. Popkin, History, Historians, \& Autobiography (Chicago/London: University of Chicago Press, 2005), 307-22, whose bibliography lists 381 historians' autobiographies in the English, French and to a lesser extent German languages, of which over 160 are book-length autobiographies, depending on how they are counted. 
young adulthoods of historians has also become a growth area. We are concerned in this chapter with three such works: Sheila Fitzpatrick's My Father's Daughter (2010); John Rickard's An Imperial Affair (2013); and James Walvin's Different Times (2014). ${ }^{2}$

The authors are of the same generation, born within eight years of each other, and spent their careers in the academy. All have safely passed their three score and 10 years and are still actively publishing, especially Fitzpatrick and Walvin. Rickard and Fitzpatrick were born in Melbourne, in 1935 and 1941 respectively; the fact that two of the texts are by Australians reflects the Australian over-representation of historians' memoirs, including those of childhood. After an earlier career in the theatre, Rickard became a historian of Australia at Monash University. Fitzpatrick, by contrast, carved out a formidable reputation as a historian of modern Russia, mostly at the University of Chicago. Walvin, by contrast again, was born in 1942 in Failsworth, in the Greater Manchester industrial belt. Based at the University of York (UK), Walvin's research interests are many, and the overlap between life and work is evident in Different Times. The historian of childhood now writes about his own childhood; the historian of Victorian values discusses mid-twentieth-century workingclass values; the historian of transatlantic slavery (Walvin's speciality) talks about working conditions in the Lancashire cotton mills and hat factories; and the historian of soccer includes a chapter on his beloved Manchester United and the Munich air disaster of 1958.

2 Sheila Fitzpatrick, My Father's Daughter: Memories of an Australian Childhood (Melbourne: Melbourne University Press, 2010); John Rickard, An Imperial Affair: Portrait of an Australian Marriage (Melbourne: Monash University Publishing, 2013); James Walvin, Different Times: Growing up in Post-War England (York: Algie Books, 2014). Other historians' autobiographies of childhood include A.L. Rowse, A Cornish Childhood (London: Jonathan Cape, 1942); Donald Horne, The Education of Young Donald (Sydney: Angus \& Robertson, 1967); Richard Cobb, Still Life: Sketches from a Tunbridge Wells Childhood (London: Chatto \& Windus, 1983); Amirah Inglis, Amirah: An UnAustralian Childhood (Melbourne: Heinemann, 1983); Bernard Smith, The Boy Adeodatus: The Portrait of a Lucky Young Bastard (Ringwood: Allen Lane, 1984); Ronald Fraser, In Search of a Past: The Manor House, Amnersfield, 1933-1945 (London: Verso, 1984); Manning Clark, The Puzzles of Childhood (Ringwood: Viking, 1989); Kathleen Fitzpatrick, Solid Bluestone Foundation and Other Memories of a Melbourne Childhood, 1908-1928 (Melbourne: Macmillan, 1989); Jill Ker Conway, The Road from Coorain (London: Heinemann, 1989); Sydney Checkland, Voices Across the Water: An Anglo-Canadian Boyhood (Aberdeen: University of Aberdeen Press, 1989); Robert Allen Rutland, A Boyhood in the Dustbowl, 1926-1934 (Niwot: University Press of Colorado, 1996); Peter Gay, My German Question: Growing Up in Nazi Berlin (New Haven/London: Yale University Press, 1998); John Molony, Luther's Pine: An Autobiography (Canberra: Pandanus Books, 2004); Helga Griffin, Sing Me that Lovely Song Again ... (Canberra: Pandanus Books, 2006); Joachim Fest, Not Me: Memoirs of a German Childhood (London: Atlantic Books, 2012); Arnold J. Bauer, Times Shadow: Remembering a Family Farm in Kansas (Lawrence: University of Kansas Press, 2012). 


\section{Contextualising}

It is in the nature of autobiography to be about 'other things' and 'other people' as well as being a depiction of the autobiographer's life, with the result that several types of content will coexist within a given autobiography. The back cover blurb describes An Imperial Affair as '[p]art biography, part autobiography, part social history'. It is also partly an autobiography of childhood, partly a family history and, as the subtitle goes, a 'portrait of an Australian marriage'. My Father's Daughter could be characterised as part autobiography, part family history (and also the portrait of her parents' marriage), part biography of her father, and in part an exploration of memory. ${ }^{3}$ The essential point is that childhood memoirs can be positioned at various points along a conceptual continuum, with autobiography at the one end and family history at the other. An Imperial Affair is located at the far end of the spectrum, focusing on Rickard's parents, Philip and Pearl. ${ }^{4}$ It contains relatively little direct autobiography, and thus presents a useful contrast for the purposes of discussion.

The three books are family histories as well as being childhood autobiographies. Individuals are almost always brought up in families, which is another ways of saying that there are no exact boundaries between a memoir of childhood and a family history. All families have secrets, or at least things they wish concealed from the outside world; these hidden dimensions can be used as a vehicle for introducing each book. Rickard's father Philip started work in 1926 at the Stores and Accounting Branch of the recently formed RAAF, rising to the rank of Group Captain. His duties involved numerous postings at home and abroad, which meant relocating his family or else being separated for extended periods. Handsome and personable, Philip needed female companionship, resulting in two affairs. Pearl was understandably devastated, especially on the second occasion, but to avoid scandal and disgrace, not to mention the effect on the children, they patched up their marriage. He ends by quoting the lines in a James McAuley poem: 'they were good people, / They cared for us and loved us' (p. 146).

3 Equally difficult to categorise are Biff Ward, In My Mother's Hands: A Disturbing Memoir of Family Life (Sydney: Allen \& Unwin, 2014); Jim Davidson, A Führer for a Father: The Domestic Face of Colonialism (Sydney: NewSouth Publishing, 2017).

4 Pearl initially called herself Mildred. For the sake of simplicity, we refer to her as Pearl, irrespective of what time in her life. 
There is also an affair in Different Times, one that was staged inside the family home. Shortly after Walvin's birth in 1942, his father (aged 32) was diagnosed with tuberculosis and spent his remaining dozen years coughing up his lungs and painfully wasting away. Across the road lived Joe Eyre, his best friend from childhood days. Joe had his own cross to bear, from the physical and psychological effects of mistreatment in Japanese POW camps. Joe visited his old friend on a daily basis and at some point he and Emma Walvin began a furtive relationship - resulting in Ian (b. 1952), who was the spitting image of his father. On this occasion, there was no recrimination, although tittering went on among neighbours and relatives. More than 20 years later, Walvin asked Jack (his father's elder brother) 'about the whole saga of Joe, Mum and the baby. Without a hint of disapproval, Jack simply said that our father knew, and didn't mind' (pp. 68-9). In a further twist to the tale, Emma Walvin and Joe Eyre never married, although they had plenty of opportunity. Joe was clearly in love with Emma, but he never proposed and she married someone else. The reason is clear enough to Walvin - namely, Joe's commitment to his own mother, the only person who had never given up hope for his safe return from the war. Joe's own wife had left him for another man during his absence and he 'resolved to care for the one woman who had stuck by him through the bleakest of times, and whose daily prayers had somehow worked. As long as his frail mother lived, Joe could not commit himself to another woman', and so he lost his opportunity (p. 68): 'I was her son before I loved you,' as the lines in Verdi's opera Il Trovatore go, 'I cannot abandon her now.'

There is nothing so dramatic in My Father's Daughter. Sheila is the daughter of the radical Australian historian and civil libertarian Brian Fitzpatrick (1905-65). There was one outright affair (pp. 51-3) and he had numerous girlfriends, platonic or otherwise, which naturally upset his wife Doff. Sheila also 'started to find Brian's girlfriends seriously irritating' (p. 106). ${ }^{5}$ This was not the only dynamic making for an uncomfortable home life. Dominating the household was Brian's heavy drinking, which ate into the family finances and prevented him getting an academic appointment

5 An account by one of 'Brian's girls', in reality a protégée, is by Beverley Kingston, 'Brian Fitzpatrick's Graduate Student: A Memoir', in Stuart Macintyre and Sheila Fitzpatrick, eds, Against the Grain: Brian Fitzpatrick and Manning Clark in Australian History and Politics (Melbourne: Melbourne University Press, 2007), 88-96. See also Fitzpatrick, My Father's Daughter, 210. 
and a secure income. Sheila was able to make her 'great escape' from what she frankly describes as an 'unhappy' family (pp. 2, 9) at age 15 when she enrolled at the University of Melbourne and lived in a residential college.

Doffs grievances with Brian and her not unjustified perception that he was the cause of her misery (pp. 17, 64) had a snowballing effect, with every new grievance piling upon the last. Bearing the brunt of her dissatisfaction was Sheila: 'My memory of my mother in these years was that life was unrelentingly hard on her, and she was unrelentingly hard on me' (p. 96). Sheila's close childhood relationship with Brian soured at adolescence when he became a repeated embarrassment to her, notably when his drunken personality took over from the sober one (pp. 105-6, 166), and it had hit 'rock bottom' when she made her 'second escape' and left for postgraduate work at Oxford. As a mark of her disapproval, she refused to answer Brian's letters when he offended her with one of his, and then suffered appalling shock and guilt when he suddenly died. There was eventual rapprochement, first with Brian's memory when Sheila returned to Australia after a 15-year absence, in 1979, and discovered that he 'had become part of the pantheon of the Left during the Whitlam era, it was an enormous relief to me; I had come to see him so strongly in pathetic terms, in terms of failure and futility' (p. 110). Reconciliation was also achieved with Doff. John Legge, the foundation professor of history at the recently created Monash University appointed Doff to a tutorship (having already rejected Brian for a position). Her confidence and self-esteem soared, her outlook on life changed, and by the 1990s she had abandoned 'a lifetime's practice in communicating grievance'. The metamorphosis of Doff and her changing relationship with Sheila are beautifully conveyed in the final pages of $M y$ Father's Daughter, where we get the definite sense that Sheila, finally, had also become her mother's daughter.

\section{The theme of change}

That there is change over time is a truism, especially in the context of the accelerating changes on all fronts in the eight decades since Rickard was born. Every autobiography deals with dissimilar times from the contemporary present, when circumstances were not the same and when people thought and acted differently. Whereas the theme of change over time is implicit in My Father's Daughter, it recurs in Different Times, as its 
very title suggests. ${ }^{6}$ One motivation to write the book stemmed from Walvin's talking to his sons and grandson: 'they listen to my tales as if I were talking about a lost Amazonian tribe. It was utterly beyond their ken'.7 Different times is also an underpinning theme in An Imperial Affair. It is also 'a portrait of a marriage' in much the same sense as is Nigel Nicolson's famous book of that title about his own parents, ${ }^{8}$ and Rickard uses the story of his parents' marriage to illuminate:

the larger story of Australia's role as a 'dominion' in the British Empire, which, although it had entered a terminal decline, still commanded the cultural allegiance of most Australians. My parents, like most middle-class folk then, took England and Empire as a given ... Australia was a much smaller and more conformist society, with a population of a mere seven million, and although the War had exposed the irrelevance of Britain to our defence, the imperial connection remained fundamental to our sense of national identity ... [World War I] was, as far as Australia was concerned, a British war in defence of empire (pp. 3, 7).

With Philip being in the air force, the forms and observances that tied Australians to loyalty to the reigning monarch were intensified in the case of the Rickard family.

The notion of the recent past being so different from the present is most pronounced in Different Times, which, as the back cover blurb states, 'weaves the personal details of one family's life into the broader story of the industrial north'. When Walvin was a youngster, his hometown of Failsworth was still dominated by the cotton industry. The characteristic chimneys of the cotton factories extended in every direction, an unrecognisably different landscape from today. Not simply the landscape but life itself was in the thrall of cotton. Although in terminal decline, cotton remained the greatest single employer, dominating the district,

6 Historians' autobiographies of childhood that make explicit comparisons between past and present are surprisingly rare. Even when their titles suggest a then-and-now approach, this does not turn out to be the case. See Paul Johnson, The Vanished Landscape: A 1930s Childhood in the Potteries (London: Weidenfeld \& Nicolson, 2004). Those that make explicit contrasts include William H. McNeill and Ruth J. McNeill, Summers Long Ago on Grandfather's Farm and in Grandmother's Kitchen (Great Barrington, MA: Berkshire Publishing, 2009); Peter FitzSimons, A Simpler Time: A Memoir of Love, Laughter, Loss and Billycarts (Sydney: HarperCollins Publishers Australia, 2010).

7 James Walvin, email, 26 November 2014.

8 Nigel Nicolson, Portrait of a Marriage: Vita Sackville-West and Harold Nicolson (London: Weidenfeld \& Nicolson, 1973, and numerous subsequent editions). 
much like the coal mines and steel factories in other parts of Britain. ${ }^{9}$ But the sites of labour that sustained life were also 'killing industries'. As well as the numerous-enough industrial accidents, respiratory diseases such as pneumoconiosis (from coal dust) killed miners and byssinosis (from the pervasive cotton fluff) saw off many cotton-factory workers (pp. 27-8, 73, 192). Walvin provides a salutary reminder that some of the conditions of labour associated with the nineteenth century persisted well into the twentieth century.

\section{Family life}

Childhood involves being part of a family. The Fitzpatrick and the Rickard households were described as being 'tight' or 'tightly knit' little families, but they mean two different things. The Fitzpatrick family was 'tight' in the sense of being 'close, crowded, tense, hard to breathe in', not to mention being hard-up (p. 9). The Rickards were 'tight' in the sense of being cohesive (p. 114). Their dynamics were quite different. They were marched in directions they did not want to go.

Doff Fitzpatrick's negativity cast a long shadow over the family, as did Brian's drinking (pp. 80-2). Both caused rifts between Sheila and her parents. The Rickards confronted an intruder of a different kind with the onset of Pearl's depressive episodes in the early 1950s followed by heart palpitations, which the doctors were unable to diagnose correctly, and eventual shock therapy for the depression. In delicate health until her death 10 years later, in 1962, Pearl endured more hospitalisations, lived in fear of a recurrence of depression and was then diagnosed with cancer of the bowel. Family life was anything but normal despite 'a sense of guarded determination to live a normal life' (p. 133). Rather, Pearl's ill-health was a brooding presence, intrusively and inescapably hovering over the family.

In the same way, the Walvins' home life was dominated by his father 'wasting away under the corrosion of tuberculosis' (p. 13). A stark childhood memory is his 'enfeebled' father coughing gouts of blood into the kitchen sink - the only sink in the house - whilst being physically supported by his wife (p. 39). This general scenario went on year in, year

9 Catherine Cookson's novel Maggie Rowan (London: Macdonald, 1954), ch. 1, compellingly portrays how a Tyneside coal-mining community was dominated at every level by living in the shadow of the pithead. 
out, and Emma was left with a 'pervading sense that there was no way out of the cycle' (p. 48). She was the breadwinner and responsible for the upbringing of two small boys. Walvin recalls the 'unrelenting drudgery' that became part of his mother's daily life. There was never enough money. Midweek the money would run out, and often too the food had run out or was running low, so that 'there was nothing to do but wait for the next pay packet, or hope for a gift or a loan from a relative or friend' (p. 48). The food itself was unappetising and unwholesome, dominated by Spam and potatoes.

It was only the kindness of friends and especially of relatives that enabled the Walvins to get through. Whereas the Rickards and the Fitzpatricks were essentially nuclear families, the Walvins were more an extended family. During their childhood, the two Walvin boys were in the care or spent time with their maternal grandparents (p. 39), which took some of the strain off their mother. The grandparents helped out by buying shoes and clothing for the children, they chipped in with financial help, and they took the boys to soccer matches and for seaside holidays at Blackpool. ${ }^{10}$ But they also gave more than material assistance; the moral support provided an emotional 'safety net' (pp. 82, 201).

The charity of friends and wider family were expressions of workingclass solidarity, but as Walvin points out the tight-knit working-class communities of Greater Manchester were essentially 'local' - that is, bound by a narrow locality - and based on nearby institutions such as 'workplaces, shops, places of worship, drink and entertainment, and schools' (p. 97). There is no nostalgia in his account, only a vision of a largely unlamented world, inhabited by the crooked timber of humanity, which nonetheless had it good points, foremost of which was a sense of responsibility to others. Help and even salvation could come from unexpected quarters. When Ian was having difficulties with his uncaring stepfather, a couple with whom the family had very little contact enabled him to escape a difficult domestic situation by taking him in as a boarder (pp. 96-7, 188). The short and simple annals of the poor make for depressing reading.

10 Seaside holidays were a national institution. During their stay in England in the late 1930s, the Rickards also went on seaside holidays, but at respectable Bournemouth rather than the more-distant and downmarket Blackpool (An Imperial Affair, 40). 
Walvin's working-class background has shaped the historian he became, as evidenced by two of his books on nineteenth-century British social history. Not only has he written about seaside holidays, which he so enjoyed in his youth, but about childhood itself, and both books are to some extent concealed autobiography. ${ }^{11}$ Much of the content of A Child's World corresponds to childhood experiences of his own. A Child's World is not only informed by the events of his own upbringing but is overwhelmingly about impoverished children, as he once was.

\section{Sexuality}

The greater willingness of contemporary autobiographers to relate more intimate detail is another indication of living in 'different times'. The same authors who might, say, 40 years ago, have been circumspect are now less restrained and move with the spirit of a more candid age. Nonetheless, Rickard, Walvin and Fitzpatrick tell markedly different tales of sexual awakening and early experiences.

When he was well into his teens, Rickard's father introduced him 'to something called "the facts of life"'. That such a highly sexed man should feel so awkward and embarrassed by his fatherly duty speaks volumes about the reticences of the age. 'You'll soon get interested in girls', he explained, a statement that struck Rickard as both 'faintly indecent' and 'highly unlikely' (pp. 113-14). If the penny does not drop, it does so 14 pages later when Rickard relates his first homosexual relationship. His parents suspect what is going on and he is outed; in what must have been an excruciating experience for all concerned, Philip and Pearl suddenly confront him, framed by the doorway to his bedroom, 'leaning forward a little, yet careful not to step into my room, as if somehow respecting my privacy while even intruding on it' (pp. 128-9). As Rickard explains elsewhere, 'for me the 1950s was a sex-free zone. Not of course that I wasn't thinking and fantasising about sex but, given the social mores of the time and my own family background, I had great difficulty coming to terms with my sexuality. ${ }^{12}$

11 James Walvin, Beside the Seaside: A Social History of the Popular Seaside Holiday (London: Allen Lane, 1978); Walvin, A Child's World: A Social History of English Childhood, 1800-1914 (Harmondsworth: Penguin Books, 1982).

12 John Rickard, 'Sydney: The Class of '51', Australian Historical Studies, 27:109 (1997), 176, doi.org/10.1080/10314619708596052. 
Walvin is equally frank in describing the lack of sexual knowledge and experience of his generation of teenagers, who went to single-sex schools where sex education was off limits. Neither were such matters discussed in family circles. There was, nonetheless, a fascination with all things sexual. Adolescent males had a rampant interest in this great unknown and would swap coarse stories, but that was pretty much the extent of it: they were 'innocents in an age of innocence' (p. 130). The height of his experience, if it can be called that, came at dancing lessons, which provided the 'fleeting opportunity to hold a girl in my arms. One girl was especially busty, and holding her close, in the last waltz, was an early experience of sexual bliss' (p. 108).

Fitzpatrick was more liberated. Living in Women's College, an affiliated residential college of the University of Melbourne, gave scope for sexual expression that would have been out of the question had she remained at home. An early entrant to university, aged 16 , her new milieu was liberating in more ways than one:

In this new world, remarkably, there were people like me; I was not [the] oddity [that I felt myself to be at high school]. I had friends, even a boyfriend. Away from home, I could forget the old dragging undertone of uneasiness, the everyday worry of what unpleasantness might turn up next (p. 128).

It also involved swapping stories with fellow students-in-residence about what awful parents they had.

It went from good to better. To solve her shyness, she had boyfriends and for the first two years was always holding someone's hand. There was a practical as well as a romantic reason - her short-sightedness presented initial difficulties in finding her way around (p. 127). There was also the discovery of sex, which was enjoyable 'both in and of itself and as a way of being close to someone', and it is difficult to imagine these days that earnest discussions within Women's College on the morality of premarital sex would be the case (p. 144). Her first serious relationship started in her second year, but neither she nor her partner was interested in marriage in Fitzpatrick's case because she 'was afraid of suffering [Doff's] dreadful fate and being deprived not only of a career but of all possibility of 
happiness and enjoyment in life' (p. 148). There were other complicated relationships. What stands out is the frankness with which they are related, without being unfair to the other person. ${ }^{13}$

\section{Music and sport}

In referring to the late 1950s 'tug of war for the cultural soul of Britain', Walvin laments the consequent polarisation of opinion and taste. There was a high-browed culture represented by so-called serious literature and classical music as opposed to a popular culture of comics, trashy novels and pop music: 'What was it going to be? Bill Haley or Barbirolli? The Brains Trust or ITV?' There was also a widespread feeling that high culture, such as orchestral music, and sport were oppositional:

From the first I thought much of the debate oddly unnecessary. Why did it have to be one or the other? Why couldn't we settle for a new kind of cultural pluralism that allowed people to pick and choose as they saw fit. Was it so odd to like the Hallé [Orchestra] and Manchester United? (p. 133).

Rickard and Fitzpatrick did not embrace cultural pluralism to the same extent. The subject of sport never comes up in An Imperial Affair, in contrast to Rickard's discussions of his parents' musical interests and his own involvement in the theatre. For her part, Fitzpatrick gave up sport altogether when she went to university 'and, having become an intellectual snob, looked down on it, especially hockey' (p. 117). Walvin, by contrast, is passionate about soccer and Manchester United - a devotion that remains undiminished, and has led him to writing books on the subject. ${ }^{14}$

Thus, Different Times includes an entire chapter on soccer, culminating in the Munich air disaster of 1958. The 23 fatalities included eight Manchester United players, the famous Busby Babes. It was not the first such soccer disaster nor the most serious, but it hit home hard: older

13 See also Peter Nicholls, 'Sheila Fitzpatrick as an Australian Teenager', in Golfo Alexapoulos, Julie Hessler and Kiril Tomoff, eds, Writing the Stalin Era: Sheila Fitzpatrick and Soviet Historiography (Basingstoke: Palgrave Macmillan, 2011), 197-202.

14 James Walvin, The People's Game: A Social History of British Football (London: Allen Lane, 1975); Walvin, Football and the Decline of Britain (Basingstoke: Macmillan, 1986), doi.org/10.1007/978-1349-18196-4. 
people averred that it felt even worse than the Blitz. ${ }^{15}$ The mood of misery in Manchester following the Munich air disaster is caught by Walvin, who was witness to the city's reactions. The hearses proceeded from Manchester airport to Old Trafford, and '[d]espite the bad weather and the time (it was almost midnight), huge crowds turned out to line the streets to pay their silent respects. The misery of it all lingered over the city like one of its infamous dark skies, and simply wouldn't go away' (p. 156). What also has not gone away, different times or not, is the behaviour of supporters - 'the raw adult vulgarity, and ... football's amazing ability to transform normal folk into demented ranters' (p. 149).

The three memoirists are in greater accord when it comes to music. It should hardly surprise that classical music continues to play a significant part in all of their lives. They were brought up at a transitional time when the radio and the gramophone represented the only switch onswitch off home entertainment, so people still had to make their own amusements, and learning a musical instrument was more in evidence than today. Despite straitened family circumstances, Fitzpatrick learned the violin from the age of five or six (just as her brother learned the piano) and received enormous encouragement from Brian, himself a lover of Beethoven (pp. 74-6). She was talented, but her approach was akin to that of her schoolwork in that she could do well with insufficient effort. Her involvement in music and playing in various orchestras was a significant part in Fitzpatrick's early life. Reflecting on her adolescent violin playing, Fitzpatrick saw it as 'quite separate from the family; that must have been one of its advantages' (p. 91). She put the violin aside at the onset of university studies. There was a brief resurgence of interest in music a few years later (p. 180), but only in later years, following a bereavement, did Fitzpatrick resume active musicianship in chamber music, mainly quartets. ${ }^{16}$

Neither Walvin nor Rickard had such intense encounters with music, but it was still a presence. Philip Rickard was a church organist and it was music that brought him and Pearl together (p. 6). Music remained 'part of the family culture' throughout their marriage: there was a ritual of sherry and music before dinner (p. 115), and they were at the heart of the church

15 Less than eight-and-a-half years earlier, an aircraft carrying the Italian champions Torino crashed with total loss of life, and again it took a full decade to rebuild the team. Paul Dietschy, 'The Superga Disaster and the Death of the "great Torino"', Soccer \& Society, 5:2 (2004), 298-310, doi. org/10.1080/1466097042000235272.

16 The original version of $M y$ Father's Daughter contained a separate chapter on music. 
choir when they finally settled in Sydney. They were also avid concert- and theatre-goers (pp. 38-9) and they instilled in Rickard a love of classical music. Although never a choirboy, the Anglican Church was and remains important for Rickard, who has written a history of his parish church in North Melbourne. ${ }^{17}$ When his voice broke, he was encouraged to take singing lessons. Later, as an actor-singer in London, he harboured ambitions for opera and lieder. More to the point, 'it was the world of theatre, always a site for cultural subversion, that offered the real [sexual] freedom I had been groping towards all along. There I came to realise that the temptation I had been resisting was in fact, for me, the truth to be embraced'. ${ }^{18}$ He only ceased his 'raffish career' in theatre in 1971, when appointed to a lectureship at Monash University. ${ }^{19}$

Walvin's musical experiences began at the age of six when he joined the local Anglican parish. Neither parent was Anglican, or musical, but Walvin was attracted to St John's because its Sunday school offered social activities and 'a range of instruction' (p. 108). There, his singing was noted by the choir mistress and he was inducted into the choir. He had the singular good fortune that a First World War veteran liked his singing voice and gave him hours of tuition. Rickard was also a choirboy and he also took singing lessons (p. 115), but these activities had a lesser effect than they did on Walvin, for whom St John's was an important part of his growing up. It had two long-term effects on Walvin. One was to provide 'an early apprenticeship for a career which required me to sing for my supper in front of students and the public' (p. 108). Second, and despite losing his faith, he acknowledges that:

the Church of England left its fingerprints all over me. Its rituals, its calendar, its hymns and liturgy, all and more remain embedded deep in my brain. Today, there are times when I feel I am one of a dying breed of Anglican survivors. In recent years I have attended funerals where the only people in church who seemed to know the hymns, prayers and protocols were me, the minister and the organist (p. 112).

17 John Rickard, An Assemblage of Decent Men and Women: A History of the Anglican Parish of St Mary's North Melbourne 1853-2000 (Melbourne: St Mary's Anglican Church, North Melbourne, 2008).

18 Rickard, 'Sydney: The Class of '51', 176.

19 Rickard has written a number of academic articles on the theatre: "A Fine Song and Dance!": Manning Clark's History - The Musical', Victorian Historical Journal, 59:3-4 (1988), 3-20; 'The Boys in the Band Revisited', Meanjin, 52:4 (1993), 661-6; 'The Melbourne Theatre Scene: A Personal Perspective', in Seamus O'Hanlon and Tanja Luckins, eds, Go! Melbourne in the Sixties (Melbourne: Circa, 2005), 17-30. 


\section{Self-representation}

The three memoirists represent their selves in quite different ways. Rickard, for the most part, remains a shadowy figure in a text which, after all, is a portrait of his parents' marriage. He is the little boy in the background, who occasionally emerges to recall an event; to accentuate the obscurity, he sometimes refers to himself as 'John', rather than by a pronoun. Only in his final year at school, followed by his tertiary education, his involvement in the theatre and sexual awakening does he emerge as a more rounded individual.

Walvin presents himself as curious and self-motivated, characteristics that coexisted with a sceptical attitude and a strain of indignation, making him a 'prickly teenager' with 'an abrasive, bolshie view of the world' (pp. 45-6, 82). He finally lost his religious faith at the age of 17 after increasingly questioning the very worth of a God who had reduced his family and those around them to such dire circumstances (p. 111). The ultimate break was a result of the vicar's enthusiastic endorsement of capital punishment, although Walvin suggests that this was the occasion rather than the cause. Walvin also bristled during the 1959 election campaign when Prime Minister Harold Macmillan used the phrase, 'You've never had it so good', which he later realised was broadly correct, but at the time it seemed a 'sneering insult' (pp. 168-9). He also admits that the English class system 'irritated me immensely' (p. 163).

Misgivings were also directed at the British Empire. The qualms initially centred on his grandparents:

What had this great empire done for them, or for my relatives and our neighbours? My grandparents lived simple, often impoverished, lives with little to show for a hard week's work except a couple of shillings deposited in the holidays savings club, and the few pennies set aside in the local burial club. Their meagre pleasures seemed a poor reward for their part in an imperial success story (p. 80).

But there was more to it. Walvin came to dislike the chauvinism and the insularity that stemmed from Britain being an imperial power. The 'demonology of foreigners' and the prevailing notion that 'abroad is beastly' were part of his environment (pp. 79, 138, 141, 181). Funnily enough, he had a treasured collection of Biggles books, those empireaffirming texts par excellence (p. 115). The circuit-breaker was a summer exchange scheme organised by his school, which had him off to France 
for a month to live with a French family. He returned a confirmed Francophile and, as a 14-year-old, was now openly questioning the prevailing assumptions that lands across the sea were a combination of 'dangerous locations, untrustworthy foreigners, foul local weather, [and] unspeakable food' (p. 135). He acknowledges that he must 'have become an irritating adolescent challenge to relatives and friends, not merely because of normal teenage awkwardness, but through my inquisitive and doubting presence' (p. 141). Some of Walvin's attitudes were a product of his particular working-class upbringing and others were a reaction against it.

Fitzpatrick presents herself with a searing and uncompromising honesty: 'As a historian I have always taken pride in putting in what I discovered ... It would have been nice to have left some things out [about myself], but I found myself unable to do so' (p. 5). It cannot be easy to write positively about an unhappy upbringing, but there are times when there is an element of the self-lacerating: 'Cynicism and pessimism were a cherished part of my chosen persona at university' (p. 127); 'I had not yet outlived my adolescent habit of sulking and was prone to moodiness' (p. 145); she refers to her 'habit of not hiding from people things that might hurt them' (p. 183); and she applies the words 'insouciant' and 'insouciance' to herself (pp. 123, 135). It is little wonder that few people write their autobiographies of childhood given how painful the requisite honesty can be, both to self and to others.

\section{Becoming historians}

The decisions of the three authors to embark on careers as academic historians involved, in varying proportions, a mix of inner urges and opportunity, deliberation and chance. There were other choices: Fitzpatrick had music; Rickard's first career was in the theatre; and Walvin might have ended up a schoolteacher but for the opening up of undergraduate places at the 'redbrick universities' in the late 1960s. In that way, numerous working-class adolescents had the opportunity of a university education that would otherwise have been beyond reach.

Neither Fitzpatrick nor Rickard particularly liked their time at secondary school. Rickard finished his schooling at Knox Grammar, a private school on Sydney's North Shore, at the time of a philistine headmaster. But two or three good teachers on the staff (although not the history teacher) gave 
him the idea of going to the University of Sydney where he enrolled for an Arts/Law degree. It was the family expectation that he would go to university and, although Philip hoped he would enrol in engineering as he would have liked for himself, he had no problem with his son doing Arts/ Law. As runner up in the Shell arts scholarship in 1956, he spent a year at Oxford but does not indicate his course of study. Nor does he say how he became a historian, apart from indicating that history was his real interest (pp. 120-2). Nowhere mentioned in An Imperial Affair is that Rickard did a potted PPE (Philosophy, Politics \& Economics) course at Oxford, for which he received a diploma. Returning to a job in Australia with Shell, he drifted into theatre to get away from corporate life, and remained in acting for 10 years. A friend arranged an introduction to meet John Legge, the history professor at Monash University, and Rickard embarked on an MA thesis. What started as 'initially something to interest me' then became a $\mathrm{PhD}$ thesis with a supporting scholarship, and eventually he was offered a lectureship in the Monash history department in 1971. This was at a time when Australian universities were still expanding, but only barely in the Monash history department. He described himself to us as 'the last expansionary appointment' in the department. ${ }^{20}$

Neither does Walvin make an extended statement on the steps along the way to becoming a historian, but he provides numerous clues. His was not a promising start given that he twice failed his 11-plus examinations, an iniquitous system whereby 11 -year-olds were 'sorted into educational sheep and goats' (pp. 119-20). Instead of enrolling in a grammar school he was consigned to a technical school and might have withered on the vine but for an enlightened headmaster, who steered the brighter students into academic subjects, and 'a handful of committed teachers' who inspired and enthused (p. 130). Another was being able to escape the impossible conditions for study at home by toddling across the road and working in Joe Eyre's front room (pp. 3, 48, 80, 183). Equally important, the Manchester Central Library was a 'home away from home' as a secondary school student, and became 'his favourite place in the whole of Manchester (apart, that is, from Old Trafford)' (pp. 33-4). He was already showing considerable motivation and self-discipline in being able to work on his own (pp. 65, 116) and he describes the Central Library as where his 'real education took place' (p. 130): 'In the end,' he writes, 'my secondary school suited me well, and what shaped my teenage education were books,

20 John Rickard, telephone interview, 28 June 2015. 
Manchester Central Library and a few devoted schoolmasters' (p. 120). The school and the library in Manchester also meant that Walvin started to experience worlds beyond the intensely localised environment of his upbringing. Interestingly, Walvin mentions that his mother's 'pervasive culture of hard work' together with the need for punctuality in his first paid job as a newspaper delivery boy 'helped establish a pattern of work that became a permanent feature of my working life' (pp. 159-60).

But what prevailed on the studious Walvin to become a historian and not something else? He is under no doubt that talking to Second World War veterans, from his mid-teens, kindled his interest, beginning with discussions with Joe Eyre over endless cups of tea in his front room (p. 11):

Initially they were all reluctant to talk to me - an awkward but curious teenager - about their experiences, but eventually they spoke up, sparking what became my lifelong curiosity about history ... I must have been cheeky and insensitive: an inquisitive teenager firing questions at older men about issues they were keen to forget and certainly didn't want to discuss (pp. x, 19).

As well as hearing about the horrors of their experiences, he was also exposed to their jingoistic and anti-foreigner attitudes (p. 135), but by this time he had returned from his first visit to France and rejected such sentiments. The Suez Crisis also contributed. Walvin could not understand the seemingly universal disparagement of Egyptians as well as the French:

How could this welter of hostility to outsiders be explained? Perhaps all this had historical roots and perhaps the explanation lay in Britain's historical past? It wasn't clear at the time, but it now seems obvious: events were pushing me towards a more serious study of history (p. 146).

A further reinforcing influence, serendipitously, was a schoolteacher introducing him to films and novels, including Orwell's The Road to Wigan Pier (1937), and to the community studies of northern English cities that were being published in the late 1950s, along with a major sociological work - Richard Hoggart's classic, The Uses of Literacy (1957), which lamented the erosion of 'authentic' working-class culture (pp. 82-5). ${ }^{21}$

21 See N. Dennis, F. Henriques and C. Slaughter, Coal is our Life: An Analysis of a Yorkshire Mining Village (London: Eyre \& Spottiswoode, 1956). Unbeknownst to Walvin, sociological studies of working-class London were also appearing. These are what Roy Porter was referring to when he described himself as being brought up in 'a stable if shabby [south London] working-class community completely undiscovered by sociologists': Porter, London: A Social History (paperback ed.; Cambridge, MA: Harvard University Press, 1998), xiii. 
There were no guarantees that Walvin would go to university, which at that time was highly selective. He got no encouragement from his family or his wider environment to progress in that direction; any books in the house, such as his Biggles collection, were kept well out of sight (p. 115). As he puts it:

[r]elatives clearly found my ideas and questions 'half-baked' (their favourite word for stupid) ... acquired, they thought, either by reading too much or, more directly, by 'letting France go to your head' - my mother's way of dismissing my new habit of querying life at large (p. 141).

My ideas were rejected as evidence of the dangers of education, and of reading too much. Grandma in particular seemed especially concerned about my reading habits. She even warned me directly: 'You mustn't read too much, our Jim. You'll get a brain tumour.' Her evidence for this amazing belief was the sad tale of a local boy who, having passed his 11+, promptly died of a brain tumour (p. 80).

Even then, a university education would have been out of the question had Walvin not won a State Scholarship and enrolled at the University College of North Staffordshire (now Keele University). It was a revelation, despite some initial social awkwardness. He was being paid to study; there were creature comforts, such as central heating and indoor lavatories; there was also a hitherto unimagined sexual freedom, even though students caught breaking the rules surrounding these matters were severely punished (especially the females). Walvin chose history over 'the intellectual desert of modern languages' (p. 197). Predictably enough, he began to distance himself from his background, not deliberately but because of sustained exposure to new influences.

The hardship of Walvin's childhood had moderated somewhat during his teens. Life became marginally easier in the 1950s and more noticeably so after 1957, as Macmillan had said (p. 170-3). More to the point, Walvin's schooling and his commitment to his studies provided a fulfilment that transcended his background - and it all turned out well in the end. While not minimising the hardship of 1940s northern England, the mellower tone of his later chapters suggest that his recounting the events has been filtered through the lens of subsequent experience.

There was always going to be a better chance that Fitzpatrick might become an academic historian, partly because Australia did not suffer the same hardships as did postwar United Kingdom. Neither was class such a barrier, resulting in a more egalitarian approach to making a career. 
Having two intellectual parents, one of whom was an historian, was a good start, and Fitzpatrick did receive an acknowledgement in her father's book The Australian Commonwealth (1956) for her help with 'verifying and correcting' (p. 103). It was also a good start that Fitzpatrick was precociously gifted and entered the University of Melbourne aged 16. Having her fees paid and receiving an allowance by virtue of winning a Commonwealth Scholarship, she felt unaccustomedly well-off. It also helped that she lived in a residential college rather than having to continue enduring an unhappy home life. She was fortunate that she gained admission to Women's College, whose rules stipulated the entrants had to be at least 17. Fitzpatrick petitioned the head of the college to waive the rule, 'arguing that [she] needed to be removed from a difficult family environment' (p. 125). After a generally unhappy time at her high school, where brains were frowned upon, Fitzpatrick quickly found a support group of intellectually minded students.

Fitzpatrick followed a conventional path in becoming an historian. It started with getting increasingly interested in history and by associating more with the 'history crowd'. Brian's reputation as a historian was also useful (p. 135). By the start of her third year, she had given up thoughts of becoming a musician, deciding that it was too insecure a career. The Melbourne history department also played its part, by implicitly provid[ing] the standard against which [the units teaching her other subjects] - the English and Russian Departments, the Conservatorium were judged and found wanting' (p. 151). Throughout, Fitzpatrick studied Russia, more by accident than by design, which provided a basis for her future career as a Russianist (pp. 133-4). Gaining a first-class honours degree in History and Music, she tutored in the history department for two-and-a-half years and published her first journal article (pp. 185-8), before departing for postgraduate study at Oxford University. Hers was, in a formal sense, a typical enough progression for a bright and aspiring student. ${ }^{22}$

22 Fitzpatrick recounts some of her experiences as a young historian in A Spy in the Archives (Melbourne: Melbourne University Press, 2013). 


\section{Motives and constraints}

Historians typically pen their memoirs towards the end of a career or in retirement. They become their own biographers from a variety of motives, just as they become historians for many reasons. Unusually, My Father's Daughter stemmed from a publisher's offer; having heard Fitzpatrick give a talk about her father, Louise Adler of Melbourne University Publishing made the approach for a more extended treatment along the same lines. ${ }^{23}$ Rickard's motivation was more personal; after finding a shoebox full of Philip's letters to Pearl, 'he began to feel the need, if only for my own sake, to unravel their story' (pp. vii, 1). Walvin, by contrast, was 'encouraged ... by friends, who having heard me talk about the stories related here, urged me to write the book' (p. vii). He elaborated in an email, saying that he had 'wanted to write something about this for years - partly personal curiosity but mainly to record a way of life that has vanished'. There was 'also the matter of aging. I realized that unless I turned to this soon, I might never be able to do it - or lose the ability and evidence to make it possible'. ${ }^{24}$ At quite another level, he was motived to write as a gesture of opposition to the elitism that typifies the autobiographies and the published letters of historians, which are overwhelmingly by the grandees and the 'toffs' of the profession. ${ }^{25} \mathrm{He}$ 'thought it right to write a humbler view - or at least from a humbler position' - another indication of fidelity to his working-class roots. It is by no means unusual for elderly historian memoirists from working- and middle-class backgrounds to 'to honor the lived worlds of their youth'. ${ }^{26}$

The question then turns on: what can decently be said about others; what ought to remain secret; what simply cannot be said? The three memoirists certainly take advantage of a climate of opinion that is more open to frankness and disclosure. Abuse narratives and explicit accounts of family tragedy are becoming commonplace. Death and disability narratives (pathographies), which often lay bare intimate details of bodily

23 The talk was turned into short memoir and published in the London Review of Books, 8 February 2007. A slightly longer version was later published as 'My Father's Daughter: A Memoir', in Macintyre and Fitzpatrick, Against the Grain, 163-9.

24 Walvin, email, 26 November 2014.

25 Walvin is referring to: A.J.P. Taylor, A Personal History (London: Hamish Hamilton, 1983); Richard Davenport-Hines and Adam Sisman, eds, One Hundred Letters from Hugh Trevor-Roper (Oxford: Oxford University Press, 2014).

26 See D.L. LeMahieu, "Scholarship Boys” in Twilight: The Memoirs of Six Humanists in PostIndustrial Britain', Journal of British Studies, 53:4 (2014), 1011-31, doi.org/10.1017/jbr.2014.110. 
malfunctionings and mental illness, have burgeoned over the past half century - an even greater growth area than historians' autobiographies has become. ${ }^{27}$ The increasing popularity of reality TV programs is another indicator of widening boundaries, especially in its appeal to voyeurism. All the same, there are restraints, often self-imposed. Rickard and Fitzpatrick would have been unlikely to have embarked on their projects had their parents been alive. The impulse would be to leave their memories undisturbed. Rickard said as much when an interviewer 'asked him what he imagine[d] his parents might have thought of the book. I don't think he found answering this question difficult. His parents' generation valued its privacy; they would surely not have welcomed the exposure of their lives to public view' ${ }^{28}$ Whereas Rickard's sister was encouraging from the outset, it was not so straightforward for Walvin. Only when his brother Ian came to terms with his parentage and could talk about it openly did Walvin feel that his autobiography of childhood was a publishable prospect. ${ }^{29}$

\section{Brief assessments}

By what means do memoirists excavate and recall the past? There was that shoebox of letters from Rickard's father to his mother, miraculously preserved (the other side of the correspondence is missing). This started him on the project as well as making it possible. The letters form the empirical core but there were other letters, this time between parents and children and between siblings (pp. 125-6, 142). His parents kept diaries while in England in the mid to late 1930s. Pearl's diaries seem less extensive (pp. 27, 40, 44, 47). Philip's diaries were seemingly kept over a longer period and contain longer entries (pp. 41-7), and they were not necessarily a private affair; on at least one occasion, at the end of a 17-day motoring holiday, he typed up 'fifteen foolscap pages, which was designed not only as their own record, but to be circulated to their families in Australia' (p. 32). Finally, there are Rickard's own diaries, which he kept from the age of 15 . The extent to which diaries can be misleading is

27 Anne Hunsacker Hawkins, Reconstructing Illness: Studies in Pathography (2nd ed.; West Lafayette: Purdue Research Foundation, 1999), 3.

28 Frank Bongiorno, 'Imperial Intimacies', review of An Imperial Affair by John Rickard, Inside Story, 19 September 2014, insidestory.org.au/imperial-intimacies (accessed 20 October 2014); see also Jeremy D. Popkin, 'Family Memoir and Self-Discovery', Life Writing, 12:2 (2015), 127-38, doi.org/10.1080/14484528.2015.1023925.

29 Walvin, email, 26 November 2014; Walvin, Different Times, 61. 
indicated by Rickard's admission that his homosexuality was something he 'could only hint at' in his earlier diaries (p. 121). In addition, Rickard engaged in wider research and drew from his knowledge of Australian history. He also engaged in 'optical research' - the term coined by a biographer of Mary Queen of Scots who 'visited every conceivable castle, quagmire, byre or whatever associated with the Queen in three countries $^{30}$ - as when he revisited Dubbo in New South Wales to gauge how the town, and more particularly the house, where he had lived almost 50 years earlier had changed (pp. 108-9).

At least two evidential points emerge from a reading of An Imperial Affair. One is the manner in which Rickard chews over the evidence, attempting to extract the last drop of meaning from a documentation that is rich in some respects but replete with omissions. The other concerns the limitations of memory, which itself is compounded by the gaps in the record. Rickard recalls a couple of dramatic incidents between his parents over Philip's infidelities (pp. 2-3, 100-1), but he was not in all places at all times. Besides, there is the fact of life for our authors that when they were growing up there were things were not said or done in front of the children' (p. 135). There was also the feeling that one's business was one's own, and if outsiders were to be kept in the dark on privacy grounds (p. 133), then so were the children. Rickard is sometimes left to remark that he has no memory of particular incidents (pp. 64, 94, 102). At one point, he mentions that 'beneath th[e] well ordered surface [of family life] there was an undertow of unhappiness which I have no memory of recognising' (p. 65). Indeed, he admits, as a young child, to having 'no inkling of what [his] mother was going through' when Pearl was taking treatment for her depressive disorder (p. 86). Rickard clearly discovered more about his parents from their letters than he ever would have imagined.

Different Times, by contrast, is not an archivally based book. Walvin had few, if any, written family records on which to draw. He did keep youthful diaries, long lost during one of several relocations. He was forced to write largely from memory, and there is always the problem in these circumstances as to what gets forgotten or misrepresented. As it is, he gives two examples of suddenly remembering long-forgotten events (pp. 89, 130). An important proviso is that his two brothers and an older cousin read

30 Antonia Fraser, 'Optical Research', in Mark Bostridge, ed., Lives for Sale: Biographers' Tales (London: Continuum, 2004), 113. 
drafts and provided their own perspectives as well as making corrections. It would be useful to know the specifics and the extent of such inputs, just as it would the extent to which Rickard's sister's sometimes 'different perspectives' had on An Imperial Marriage. ${ }^{31}$ Another qualification is that Walvin drew on his previous researches when giving historical context to matters such as tuberculosis, cotton, Hoggart and soccer. As with Rickard, there was the visiting of old haunts - 'a helpful jogger of memories' and the use of family photos. The latter seemed inconsequential initially because they are atypical in the sense that everyone is attired in their Sunday best, in keeping with Emma Walvin's concern for outward appearances as the confirmation of respectability. As Walvin explains, the photos are 'both misleading and revealing. Though we looked nothing like that in normal, everyday life, our Whitsuntide appearance provides a telling insight into some of our mother's most cherished values' (pp. 51-2). But they turned out to be very useful, so more the pity that none appear in Different Times. Although it was not archivally based, Walvin's aim was to write a book that will stand or fall by the quality of the writing and how far it evokes a past time. ${ }^{32}$

As well as recounting some of his own childhood, Walvin presents a remembrance of working-class life that locates his family within the broader story of the industrial north during the 1940s and 1950s. In doing so, he stresses that much of what his friends and family experienced was illustrative rather than exceptional. Joe Eyre's was 'a story in miniature' (p. 4) - he was 'one of untold legions who came home from the war harbouring hidden scars that troubled him to his dying days' (p. xi). He and his estranged wife were 'one tiny example of what was happening worldwide, as millions of people struggled to piece together lives shattered by warfare and upheaval' (p. 68). Walvin's father's illness and slow decline, awful though it was, was 'a common and familiar story' (p. 36). Many other women besides his mother 'were wrestling with similar circumstances' in the postwar years (p. 46). Eric Richards is an exact contemporary of Walvin

31 Inputs of siblings should not be underestimated. Gilbert Murray (1866-1957) regretted that his two elder brothers were 'no longer here to correct and amplify my record' when writing his own autobiography. Quoted in Francis West, 'A Broken Mirror: Gilbert Murray's Reflections on an Australian Childhood', in Christopher Stary, ed., Gilbert Murray Reassessed (Oxford: Oxford University Press, 2007), 33.

32 Walvin, email, 26 November 2014. 
and he too grew up in working-class Britain. Also a grammar school boy who went to a red-brick university on a scholarship, Richards predicts that Different Times will become a primary document of its times. ${ }^{33}$

Fitzpatrick wrote the first draft of My Father's Daughter entirely from memory. She then compared her memory with her parents' papers in the National Library of Australia, and other family papers, talked to friends and family members, and checked other archival sources. She was horrified at the fragility of her memory: 'practically everything I remembered was slightly or significantly wrong, or at any rate contested by other accounts' (p. 6).$^{34}$ It would be more than useful to have had these itemised in footnotes, but Fitzpatrick does give numerous clues in the body of her text. The book she writes also bears the hallmarks of an essentially objectivist approach to history, in itself an offshoot of her study of Russian history where she had to steer between the shoals of the competing and polarised dominant interpretations. ${ }^{35}$ She draws a distinction between 'honesty as emotional truth and honesty as factual accuracy' (p. 5) and says she is 'writing memoirs, not a history of my life' (p. 8). Fitzpatrick equates 'emotional truth' with what she remembers, as distinct from strict factual accuracy. Yet, in practice, she still writes very much as a historian and this concern with fidelity to fact and nuance is the major strength of My Father's Daughter.

\section{Final remarks}

This chapter is not intended as a cheerleading narrative about the bountiful virtues of historians' autobiographies. Their variations in quality preclude such a tactic. But we do feel that they ought to be more highly valued than they probably are at present, and childhood memoirs in particular. Historians' accounts of their childhood are often the best parts of their autobiographies. They are typically less inhibited and circumspect than the accounts of their careers. Once the memoir intrudes onto academic

33 Eric Richards, 'Emigrants and Migrants', in Philip Payton, ed., Emigrants and Migrants: Essays in Honour of Eric Richards (Adelaide: Wakefield Press, 2017), 142.

34 See also Sheila Fitzpatrick, 'Can You Write a History of Yourself: Thoughts of a Historian turned Memoirist', Griffith Review, 33 (2011), griffithreview.com/edition-33-such-is-life/can-you-write-ahistory-of-yourself.

35 See Michael David-Fox, Peter Holquist and Alexander M. Martin, 'An Interview with Sheila Fitzpatrick', Kritika, 8:3 (2007), 479-86, doi.org/10.1353/kri.2007.0034; Fitzpatrick, 'Revisionism in Soviet History', History \& Theory, 46 (2007), 77-91, doi.org/10.1111/j.1468-2303.2007.00429.x. 
life there are, as Popkin observes, tacit rules surrounding the 'obligations to maintain the group's image in the eyes of outsiders', which lends a certain blandness to many historians' autobiographies. ${ }^{36}$ Perhaps this is a common malaise for academic autobiographies generally, rather than being specific to historians. A.J.P. Taylor, as one of his biographers points out, 'did himself no [professional] favours' by writing an autobiography (A Personal History, 1983) that was inaccurate, spiteful and disparaging of others. ${ }^{37} \mathrm{He}$ broke all the unwritten rules. In writing memoirs of childhood, however, historians need not worry about professional censure of that sort and they typically have a frankness and freshness about them, although the sensibilities of family members may have some bearing on content. The problem with the genre is that one's childhood is the time of life where the written record is likely to be at its sparsest, and where memory is the principal source.

A more important consideration is that historians' autobiographies, whether of childhood or beyond, are becoming more monographic - in the sense of being research-based - as the three memoirists have demonstrated. ${ }^{38}$ Neither do historians typically find the task of autobiography an easy one. Rickard hints as much in acknowledging the help of members of an academic life-writing group in Melbourne (p. vii), and this despite a comparable experience in writing about the dynamics of Alfred Deakin's family. ${ }^{39}$ Of course, there are 'good' autobiographies and 'bad' autobiographies, just as there are 'good' monographs and 'bad' monographs. We doubt whether the three memoirists would regard their autobiographies as their most important work, but this is not to downplay their merits. Each book was a serious undertaking, involving all the historian's skills. They were written with a concern to 'get it right', or at least as accurately as could be managed. Is it not high time that historians' autobiographies of this sort receive the credit due to them as serious pieces of research?

\footnotetext{
36 Popkin, History, Historians, \& Autobiography, 152.

37 Kathleen Burk, Troublemaker: The Life and History of A.J.P. Taylor (New Haven/London: Yale University Press, 2000), 365.

38 And generational family histories by historians even more so, because their authors are dealing in large part with events before they were born and are therefore dependent on archival sources: e.g. David Walker, Not Dark Yet: A Personal History (Sydney: Giramondo, 2011); Graeme Davison, Lost Relations: Fortunes of my Family in Australia's Golden Age (Sydney: Allen \& Unwin, 2015).

39 John Rickard, A Family Romance: The Deakins at Home (Melbourne: Melbourne University Press, 1996).
} 
This text is taken from Clio's Lives: Biographies and Autobiographies of Historians, edited by Doug Munro and John G. Reid, published 2017 by ANU Press, The Australian National University, Canberra, Australia.

dx.doi.org/10.22459/CL.10.2017.03 